\title{
Land Cover Change Monitoring In Egypt Using Satellite Imagery
}

\author{
Taher M.H. Yossif \\ Pedology Dept., Water Resources and Desert Soils Division, Desert Research Center, El-Matariya, \\ Cairo, Egypt.
}

Received: 20 May 2019/ Accepted 10 July 2019/ Publication date: 20 July 2019

\begin{abstract}
An apt and effective automated methodology for monitoring land cover dynamics over time is of great importance to realize sustainable agricultural development. The present study focuses on the assessment of the trends and drivers of land cover change in Egypt for the last two decades (20002019). An approach of multi-temporal mid resolution satellite images of ETM 2000, and OLI 2019 combined with visual interpretation, supervised classification and remotely sensed NDVI and NDWI images to enhance accuracy of land cover classification was used. Results showed that Egypt could be distinguished to several land cover classes; namely, "agro-forest areas", "shrubs, grasslands and sparsely vegetated areas", "cropland", "wetland", "artificial surfaces", "bare land" and "water bodies". Over the last two decades, there has been an improvement in land cover reached around $11976 \mathrm{~km}^{2}$ (1.2\% of the total land area), simultaneously with the degradation of around $1817 \mathrm{~km}^{2}$ $(0.18 \%$ of the total land area). The study showed a crucial evidence for a prominent increase in wetland and water bodies and the consequent hazards to the croplands. It is indicated that the application of multi-spectral satellite data proved inevitably efficient, reliable and fast methods and techniques.
\end{abstract}

Keywords: Land cover; Land cover change; Land degradation; Remote Sensing; GIS; Egypt.

\section{Introduction}

Land cover (LC) as a geographical form is a reference principle for several process i.e. combating desertification, climate change, bio-diversity, range land monitoring, etc. It describes the distribution of vegetation types, as well as bare rocks/soils, inland water bodies and the anthropogenic impact (FAO, 2016). UNCCD (2013) reported that the changes in land cover point to a degradation problem due to a loss of desirable ecosystem services and recommended three (3) indicative landbased trends related to land cover, land productivity and carbon stocks above and below ground, for tracing the progress of the desired land degradation neutrality. In addition, other sub-indicators to calculate SDG index has been recommended.

As temporal dynamics of satellite imagery is instrumental in monitoring and assessing possible changes, therefore; precise surveys and data updating are required (Lambin et al., 2003 and Giri et al., 2005). Roy et al., (2002) and Ghabour and Daels (1993) indicated that efficient and automated change detection technique is essential in determining the change between dates that are uncharacteristic of normal variation. Several studies have given a consideration toward achieving accurate monitoring changes in diverse environments (Chan et al., 2001; Muchoney and Haack, 1994; Singh, 1989).

Remote sensing data and techniques have been widely used where multi-spectral data i.e. MSS, TM, ETM, SPOT etc. proved useful in detecting, mapping and monitoring land cover degradation (Dwivedi, 2001; Verma et al., 1994).

Diverse studies have been done in Egypt using satellite imagery. Sadek (1993) determined the boundaries of arable lands and followed up the extension of the newly reclaimed desert areas. Lenney et al., (1996) reported an accelerated rate of land reclamation from 1986 - 1993 and rather low rate of urbanization at the expense of the arable land. Nevertheless, there have been serious consequences of land degradation (Shalaby et al., 2004 and Suliman, 1991).

According to Springborg (1979), there has been an unfavorable population growth in proportion to the agricultural land area, which urged the government of Egypt to take an immediate action toward

Corresponding Author: Taher M. H. Yossif, Pedology Dept., Water Resources and Desert Soils Division, Desert Research Center, El-Matariya, Cairo, Egypt.

E-mail: taheryossif@yahoo.com 
the realization of approaching the self-sufficiency policy in terms of food production via rehabilitating fertility of the existing arable land at that time, besides reclaiming new desert areas.

The present study aims to monitor the actual changes in land cover pattern and identify their causes over the last two decades (2000 - 2019), using satellite imagery, GIS facilities, ground truth and Lab analysis.

\section{Description of the Study Area}

Egypt, located in Northeast Africa, has an area of about one million $\mathrm{km}^{2}$. Egypt has coastlines on both the Mediterranean Sea and the Red Sea. Egypt borders Libya to the west, the Gaza Strip to the northeast, and Sudan to the south, (Map 1). The domain Egyptian land is desert interrupted by the Nile Valley and Delta land which together represent about $4 \%$ of the country's total area. The land surface rises up on both sides of the valley to reach around $800 \mathrm{~m}$ above sea level in the west side and around $1000 \mathrm{~m}$ above sea level in the east side. The relief is characterized by low-lying sand dunes cover and depressions of the Western Deserts. East of the Nile valley, the arid Arabian Desert expands to the borders of the Red Sea. In the far southwest, the land rises into the Gilf Kebir plateau, with elevations near $609 \mathrm{~m}$. In the far southeast, the Red Sea Mountains, an extension of the Ethiopian Highlands, continue on into Sudan. The highest elevation, located at Mount Catherine in the Sinai, is $2614 \mathrm{~m}$ above sea level and the lowest elevation, at the Qattara Depression in the northwest, is $139 \mathrm{~m}$ below sea level. The population of Egypt estimates of about 100 million in 2019.

Most of the agricultural land is located close to the Nile River stream and in between and around the Nile Delta branches. Along with the Mediterranean coast, rangeland is restricted to a narrow strip which is only a few kilometers wide and its land capability is quite low. Egypt doesn't have natural forest. The total agricultural area (seasonal and permanent crops) represents about $4.1 \%$ of the country's total area which is 4.141 million hectares (ha). Egypt's climate falls within the hyperarid region with annual rainfall in most parts of less than $50 \mathrm{~mm}$. However, annual rainfall varies from about $200 \mathrm{~mm}$ in the northern coastal region to near zero in the south with warm and mild weather in winter and spring, hot and dry weather in summer and autumn. Summer temperatures are as extremely high as $37^{\circ} \mathrm{C}$ to $44^{\circ} \mathrm{C}$ and as high as $49^{\circ} \mathrm{C}$ in the western and southern deserts. The northern areas on the Mediterranean coast are as cool as $32^{\circ} \mathrm{C}$.

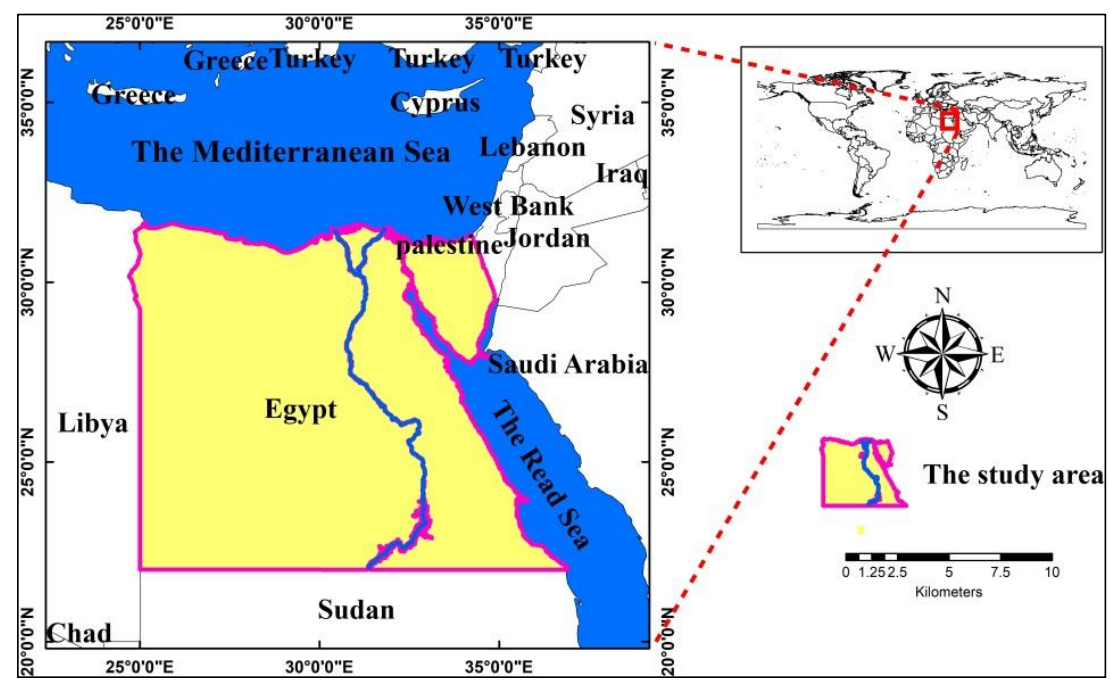

Map 1: Location of the study area (Egypt).

\section{Materials and Methods}

In order to shed the light on the dynamics of the spatial distribution pattern of the land cover in Egypt from 2000 to 2019, the following methodology has been applied:

A number of 56 False Color Composite (FCC) Landsat 7 ETM data of 2000 and Landsat 8 OLI data 2019 of Egypt, obtained from USGS (2019), were mosaicked after applying the atmospheric correction and geometric correction (Figs 1 and 2). Geometric correction was carried out using ground control points from topographic maps with scale of 1:50000 produced in 2000 (Egyptian Military 
Survey Authority, 2000) to rectify the sets of images in 2000 that were later used to rectify the sets of images in 2019. The root mean-square error (RMSE) between the two dates of images was less than 0.4 pixel which is acceptable.

Satellite data have been merged and processed with Digital Elevation Model (SRTM) of 30 meter resolution and enhanced by using the ERDAS Imagine software 16.5 (ERDAS Inc., 2018) for image classification process (Campbell, 1987; Thomas et al., 1987) to categorize all pixels in an image into corresponding land cover classes.

Visual interpretability of images could be realized through the enhancement of images by increasing the apparent distinction among the different features (Lillesand and Kiefer, 2000). Contrast stretching technique was applied on the two sets of images to ease the separation among the different classes of land cover. The two sets of images were visually interpreted using on screen digitizing in order to delineate land cover classes (Maps 2 and 3). Supervised classification was done using ground checkpoints and digital topographic maps (Maps 4 and 5). Some classes were spectrally confused and could not be separated well by supervised classification and hence visual interpretation was required to separate them. The indices of NDVI and NDWI corresponding to the normalized difference vegetation and normalized difference water were applied. The integration of the visual interpretation and supervised digital image classification in addition to the two indices and Land Cover Classification System (LCCS) of the Inter-governmental Panel on Climate Change (IPCC, 2006), land cover of Egypt was classified into seven main classes e.g. "agro-forest areas", "shrubs, grasslands and sparsely vegetated areas", "cropland", "wetland", "artificial areas", "bare land", "water bodies" (Table 1).

Assessment of the classification accuracy was done using 3000 check points (2000 point from field data and 1000 points given on the topographic maps). The locations of the 3000 points were chosen via a random stratified method to represent different land cover classes of Egypt. In order to enhance the accuracy of land cover mapping of the two sets of images (2000 and 2019), ground validation data and the result of visual interpretation were integrated with the supervised classification result using GIS to produce the results presented in Table (2).

Cross-tabulation analysis, to analyze the spatial distribution of land cover classes and determine the changes of land cover within the last two decades, was conducted using CROSSTAB tool of Arc GIS software (Table 3 and map 6) (ESRI, 2016).Validations of the methodology were carried out using high-resolution Google Earth images.

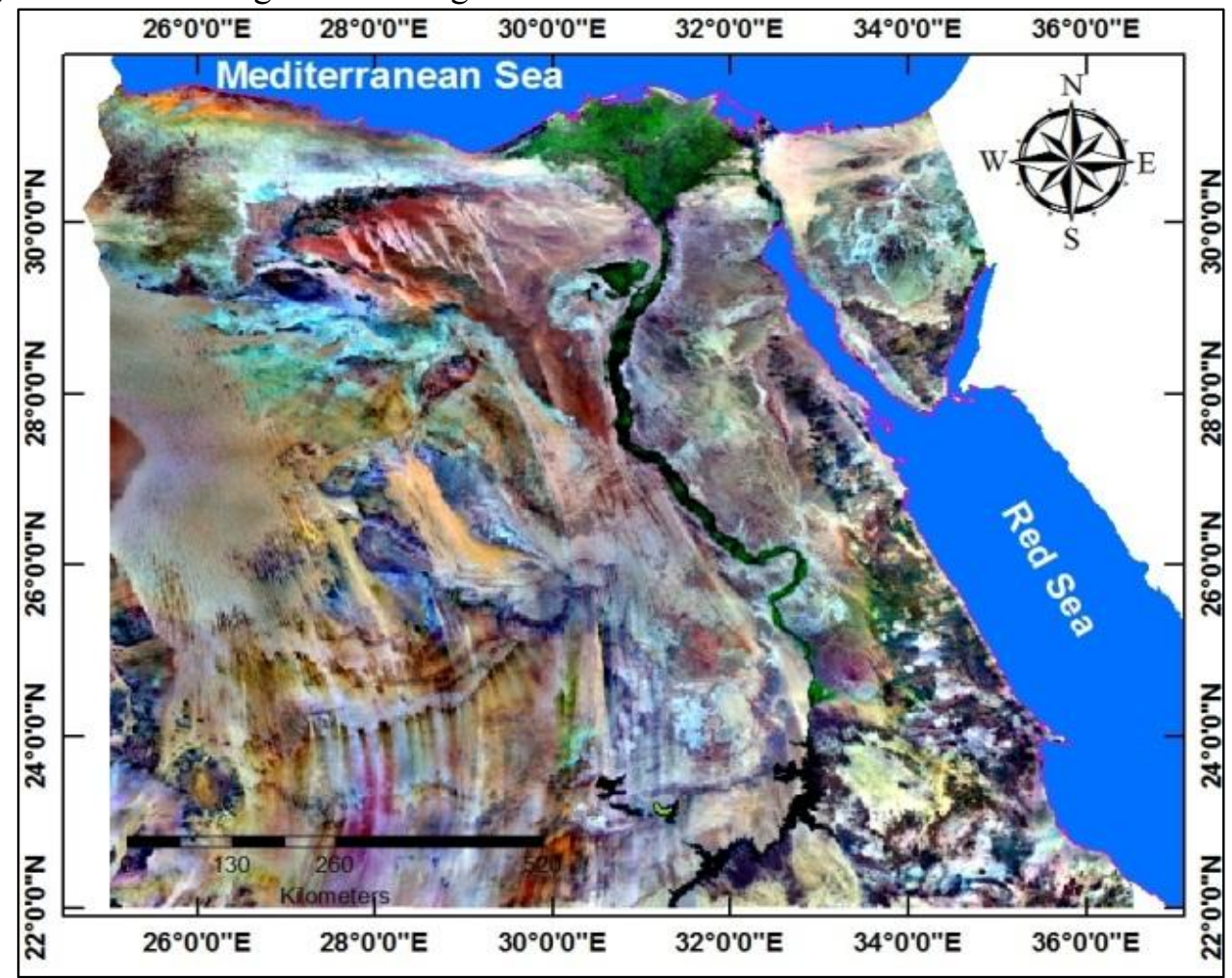

Fig. 1: FCC Landsat 7 ETM image acquired in 2000 (bands 7, 4, 2) of Egypt. 


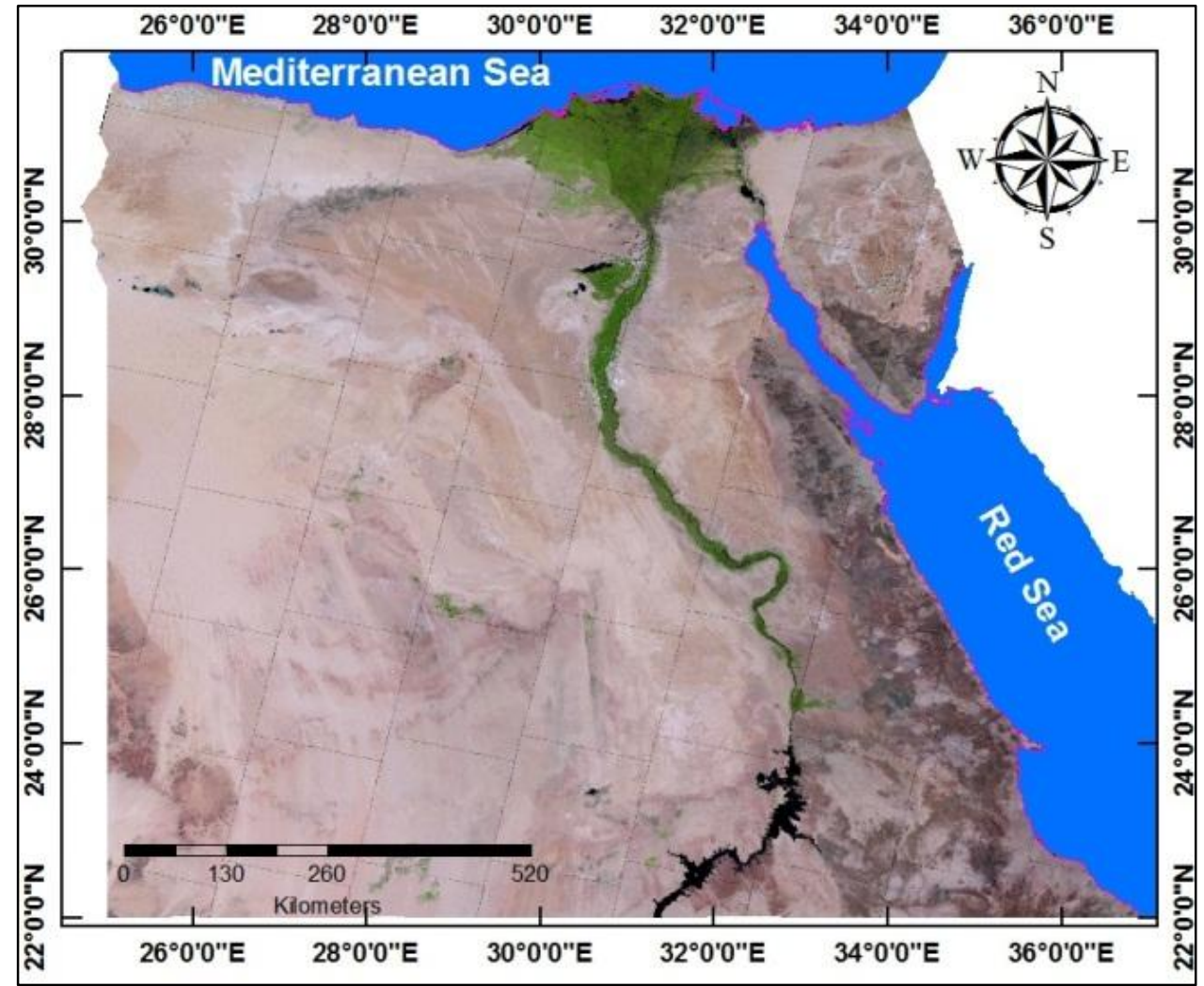

Fig. 2: FCC Landsat 8 OLI image acquired in 2019 (bands 7, 5, 3) of Egypt.

Table 1: Description of different land cover classes in Egypt after (IPPC, 2006).

\section{Class}

Agro-forest

Shrubs, grasses

and sparse

vegetation

Cropland

Wetland

Artificial areas

Bare land

Water bodies

\section{Description}

Cultivated woody trees covering between 15 to $100 \%$, mostly irrigated by waste and/or saline water.

Annuals, perennial grasses; perennial herbs and sub-shrubs; evergreen nonsucculent sub-shrubs, partially deciduous perennial sub-shrubs; evergreen succulent perennial shrubs; and deciduous perennial shrubs and scattered trees with less than $15 \%$.

Cultivated herbaceous plants; permanent cultivated tree or shrub crops and including Orchards, rainfed and/or irrigated.

Includes coastal mangroves, inland marshes, Peat bogs, intertidal flats, marshes, swamps and aquatic beds. They represent the transitional zone between terrestrial and aquatic systems, where shallow water table occurs or land might be covered with shallow water.

Any urban areas i.e. parks, industrial areas, waste dump deposits; construction sites; port, airport areas; mineral extraction, etc.

Natural abiotic surfaces (bare soil, sand, rocks, etc.), except for coastal areas affected by the tidal movement of salt water, dunes, beaches Inland water bodies (year around), such as lakes and/or river. Also, areas covered by water due to the construction of reservoirs, canals, artificial lakes, etc.

\section{Results and Discussion}

\section{A- Land cover changes between 2000-2019}

Based on the integration between visual interpretation, supervised classification, NDVI and NDWI indices, cross-tabulation analysis and field observation; land cover and land cover changes are presented in tables ( 2 and 3 ) and maps 2, 3, 45 and 6 . The results indicate the following: 
The acreage of agro-forest class increased from $4.5 \mathrm{~km}^{2}(0.0004 \%)$ in the year 2000 to $5.1 \mathrm{~km}^{2}$ $(0.001 \%)$ in $(2019)$ of the total area showing vegetation gain of $0.0006 \%$ due to practicing afforestation. Data in table (3) showed that out of the $4.5 \mathrm{~km}^{2}, 0.4 \mathrm{~km}^{2}$ converted to cropland and 0.2 $\mathrm{km}^{2}$ was inundated. Only $3.9 \mathrm{~km}^{2}$ remained agro-forest.

With respect to shrubs, grasses and sparsely vegetated areas, data show negative change $(-0.1 \%$ of the total area) from $15088.6 \mathrm{~km}^{2}(1.5 \%)$ in 2000 to $14252.7 \mathrm{~km}^{2}(1.4 \%)$ in 2019 because of the extension of urban and cropland areas. In this connection, around $159.8 \mathrm{~km}^{2}$ has been transformed into cropland class, and in the meantime around $49.6 \mathrm{~km}^{2}$ has been transformed to bare lands due to injurious human activities leading to land degradation. At the same time, $7.2 \mathrm{~km}^{2}$ (water bodies) and $1.8 \mathrm{~km}^{2}$ (bare land) have turned into shrubs and grasses.

In connection with cropland, slight increase has been realized where its area changed from $33989.3 \mathrm{~km}^{2}(3.4 \%)$ in 2000 to $42066.2 \mathrm{~km}^{2}$ (4.2\%) in 2019 due to agricultural expansion by $0.8 \%$ in the desert lands over the last 2 decades. Noteworthy to state that out of the area occupied by this class in the year 2000 , only $32832.4 \mathrm{~km}^{2}$ remained belonging to the same class in the year 2019 , whereas $1068.3 \mathrm{~km}^{2}$ has been converted to artificial areas; $55.1 \mathrm{~km}^{2}$ to water bodies and $26.1 \mathrm{~km}^{2}$ to bare land. At the meantime, an increase in cropland was $9039.9 \mathrm{~km}^{2}$ from bare land, $159.8 \mathrm{~km}^{2}$ from shrubs, $24.1 \mathrm{~km}^{2}$ from water bodies, $9.6 \mathrm{~km}^{2}$ from wetland and $0.4 \mathrm{~km}^{2}$ from agro-forest.

Artificial areas increased from $1466 \mathrm{~km}^{2}(0.1 \%)$ in 2000 to $3486.4 \mathrm{~km}^{2}(0.3 \%)$ in 2019 at the expense of the bare lands and agricultural lands with $0.2 \%$ of the total area due to the rapid population growth and the economic development; meanwhile, bare lands, covering an area of $940476 \mathrm{~km}^{2}$ in 2000 and $929552.4 \mathrm{~km}^{2}$ in 2019 , indicated utilization of $10923.5 \mathrm{~km}^{2}$ from the total area. Nevertheless, through cross-tabulation analysis it was found that $9039.9 \mathrm{~km}^{2}$ out of the bare land was reclaimed into cropland; $1.8 \mathrm{~km}^{2}$ converted to grass land and $273.1 \mathrm{~km}^{2}$ converted to artificial areas indicating a positive change. However, only $3105.9 \mathrm{~km}^{2}$ was degraded turning into water bodies and wetlands.

Water bodies increased from $9412.4 \mathrm{~km}^{2}(0.9 \%)$ in 2000 to $10122.7 \mathrm{~km}^{2}(1.0 \%)$ in 2019 of the total area, showing more land degradation mostly at the expense of $2106.8 \mathrm{~km}^{2}$ of the bare land, 35.6 $\mathrm{km}^{2}$ of wetlands. At the meantime wetlands increased from $9563.4 \mathrm{~km}^{2}(0.9 \%)$ in 2000 to 10514.6 $\mathrm{km}^{2}(1.0 \%)$ in 2019 with a change of $951.2 \mathrm{~km}^{2}$ representing $0.1 \%$ of the total surface of Egypt showing more degradation mostly at the expense of $999.1 \mathrm{~km}^{2}$ of the bare lands and $1.3 \mathrm{~km}^{2}$ of the croplands.

Table 2: National level estimates of area and net area change of the distribution of the main land cover classes between 2000 and 2019.

\begin{tabular}{|c|c|c|c|c|c|c|}
\hline \multirow[t]{2}{*}{ Class name } & \multicolumn{2}{|c|}{ LC area in 2000} & \multicolumn{2}{|c|}{$\begin{array}{c}\text { LC area in } \\
2019\end{array}$} & \multicolumn{2}{|c|}{ Net area change } \\
\hline & $\mathbf{K m}^{2}$ & $\%$ & $\mathrm{Km}^{2}$ & $\%$ & $\mathbf{K m}^{2}$ & $\%$ \\
\hline Agro-forest areas & 4.5 & 0.0004 & 5.1 & 0.001 & 0.6 & 0.0006 \\
\hline Shrubs, grasslands and sparsely vegetated areas & 15088.6 & 1.5 & 14252.7 & 1.4 & -835.8 & -0.1 \\
\hline Croplands & 33989.3 & 3.4 & 42066.2 & 4.2 & 8076.8 & 0.8 \\
\hline Wetlands & 9563.4 & 0.9 & 10514.6 & 1.0 & 951.2 & 0.1 \\
\hline Artificial areas & 1466.0 & 0.1 & 3486.4 & 0.3 & 2020.4 & 0.2 \\
\hline Bare lands & 940476.0 & 93.1 & 929552.4 & 92.0 & -10923.5 & -1.1 \\
\hline Water bodies & 9412.4 & 0.9 & 10122.7 & 1.0 & 710.4 & 0.1 \\
\hline Total & 1010000 & 100 & 1010000 & 100 & 0 & 0 \\
\hline
\end{tabular}




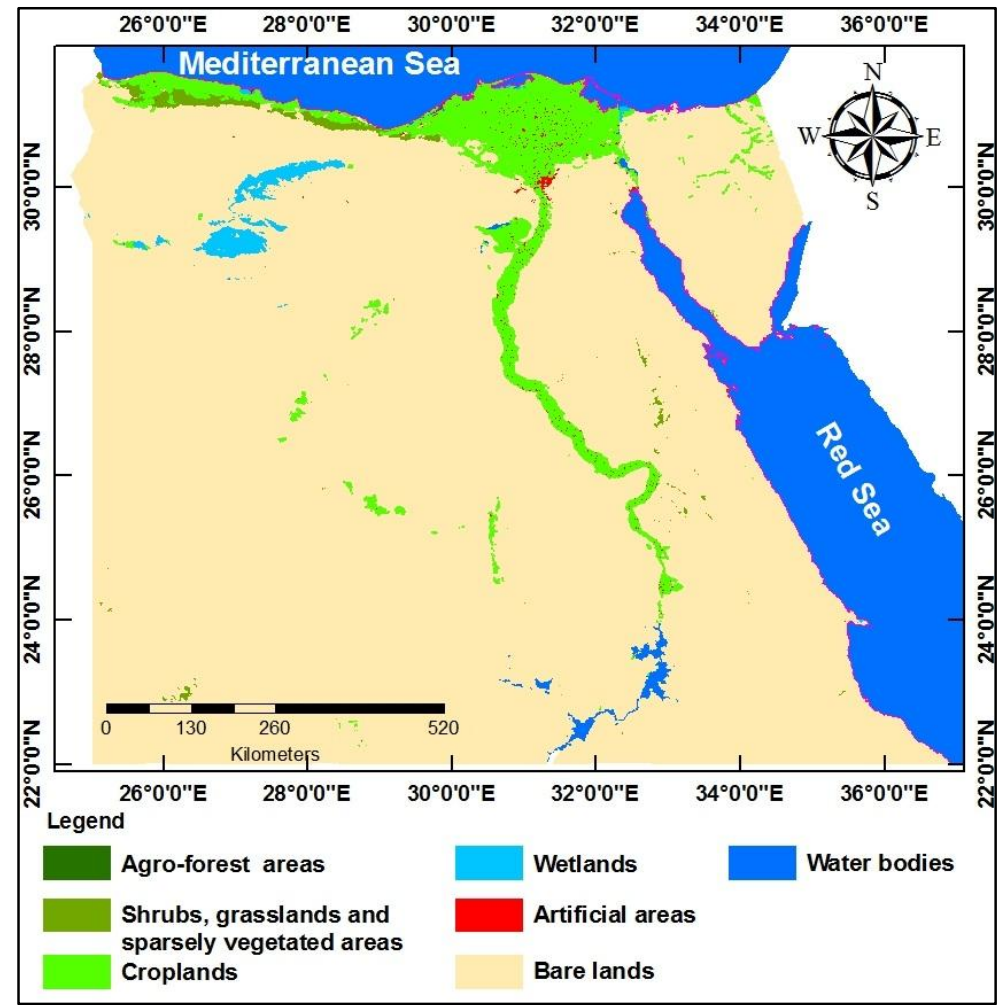

Map 2: Land cover classes as visually interpreted via screen digitizing using FCC Landsat TM 2000 for Egypt.

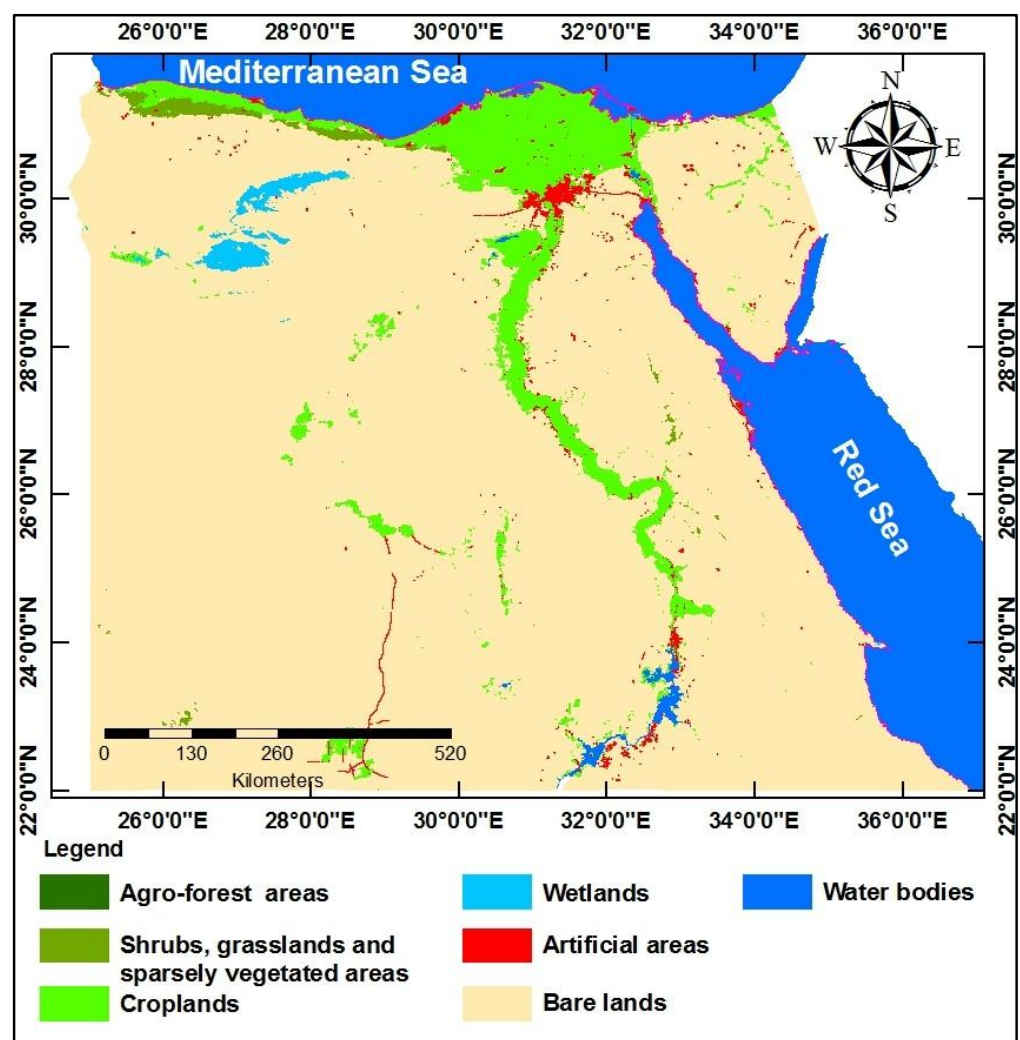

Map 3: Land cover classes as visually interpreted via screen digitizing using FCC Landsat 8 OLI 2019 for Egypt. 


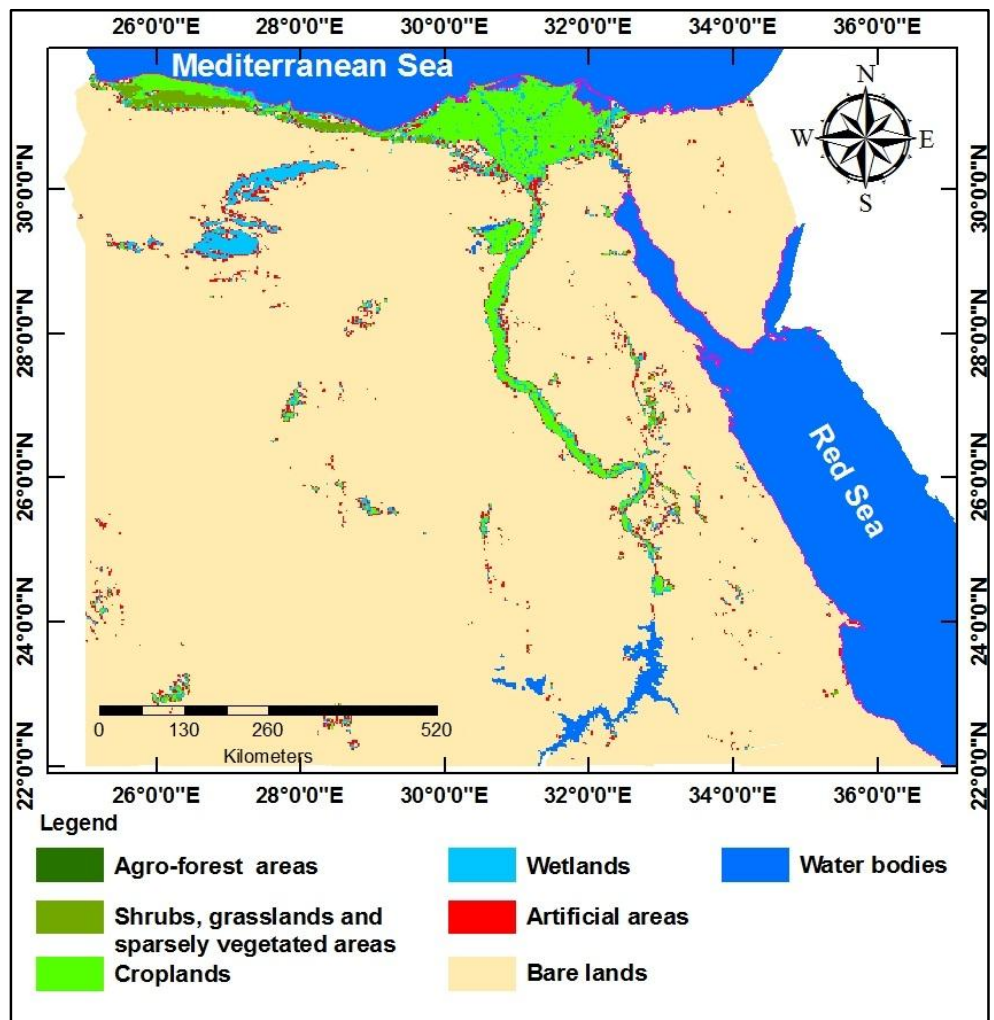

Map 4: Land cover supervised classification using Landsat ETM 2000 for Egypt.

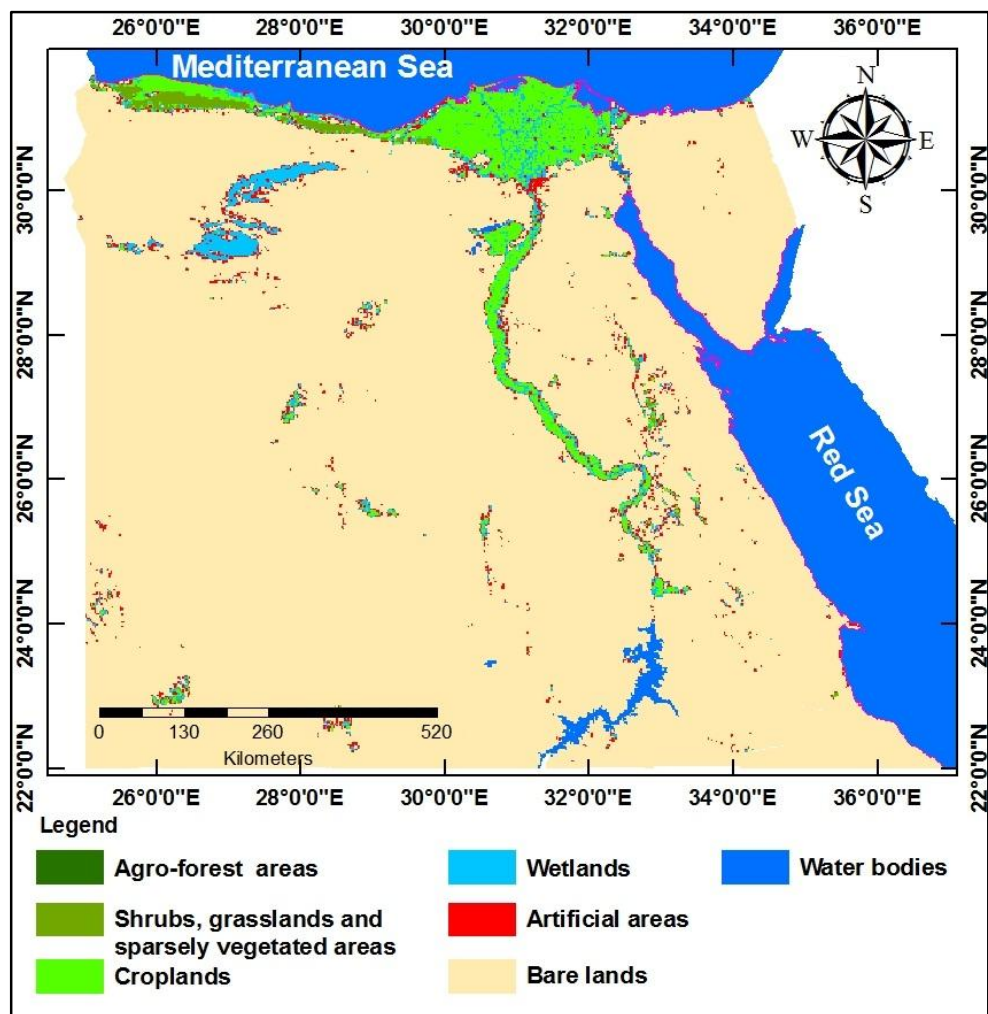

Map 5: Land cover supervised classification using Landsat OLI 2019 for Egypt. 
Table 3: Cross-tabulation of land cover area change $\left(\mathrm{km}^{2}\right)$ between 2000 and 2019.

\begin{tabular}{|c|c|c|c|c|c|c|c|c|c|}
\hline & \multicolumn{8}{|c|}{2019} \\
\hline & & $\begin{array}{l}\text { Agro- } \\
\text { forest } \\
\text { areas }\end{array}$ & $\begin{array}{c}\text { Shrubs, } \\
\text { grasslands } \\
\text { and sparsely } \\
\text { vegetated } \\
\text { areas } \\
\end{array}$ & Croplands & Wetlands & $\begin{array}{l}\text { Artifici } \\
\text { al areas }\end{array}$ & $\begin{array}{l}\text { Bare } \\
\text { lands }\end{array}$ & $\begin{array}{l}\text { Water } \\
\text { bodies }\end{array}$ & Total \\
\hline \multirow{8}{*}{ ఫ్రి } & $\begin{array}{l}\text { Agro-forest } \\
\text { areas }\end{array}$ & 3.9 & 0.0 & 0.4 & 0.0 & 0.0 & 0.0 & 0.2 & 4.5 \\
\hline & $\begin{array}{l}\text { Shrubs, } \\
\text { grasslands and } \\
\text { sparsely } \\
\text { vegetated areas }\end{array}$ & 0.0 & 14237 & 159.8 & 0.3 & 637.5 & 49.6 & 4.4 & 15088.6 \\
\hline & Croplands & 0.0 & 6 & 32832.4 & 1.3 & 1068.3 & 26.1 & 55.1 & 33989.3 \\
\hline & Wetlands & 0.0 & 0.8 & 9.6 & 9490.4 & 27 & 0.0 & 35.6 & 9563.4 \\
\hline & Artificial areas & 0.0 & 0.0 & 0.0 & 0.0 & 1466 & 0.0 & 0.0 & 1466 \\
\hline & Bare lands & 0.3 & 1.8 & 9039.9 & 999.1 & 273.1 & 928055 & 2106.8 & 940476 \\
\hline & Water bodies & 0.9 & 7.2 & 24.1 & 23.5 & 14.5 & 1421.6 & 7920.6 & 9412.4 \\
\hline & Total: & 5.1 & 14252.7 & 42066.2 & 10514.6 & 3486.4 & 929552.4 & 10122.7 & 1010000 \\
\hline
\end{tabular}

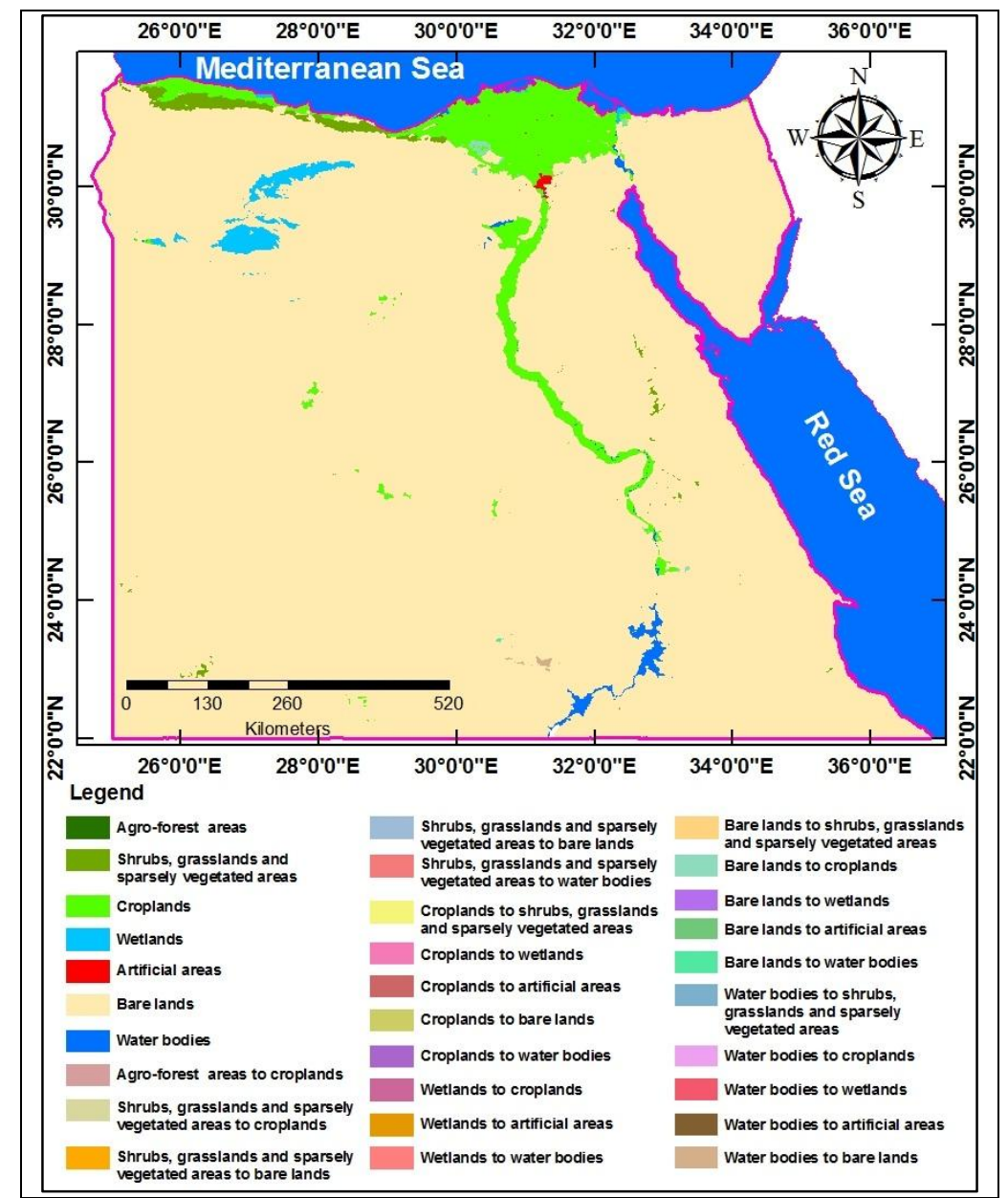

Map 6: Land cover change image between 2000 and 2019 for Egypt.

Table (4) and map (7) summarize the change in land cover occurred in Egypt during the period from 2000 to 2019 in terms of the stable, improved and degraded lands. It was indicated that the land area with improved land cover became $11976 \mathrm{~km}^{2}(1.2 \%)$, land area without change (stable) was $986085 \mathrm{~km}^{2}(98.62 \%)$ and land area with degraded land cover came to $1817 \mathrm{~km}^{2}(0.18 \%)$ of the total 
area of Egypt's land considering that the inner water bodies occupy an area of $10122.7 \mathrm{~km}^{2}(1 \%)$ in 2019.

Table 4: Summary of land cover change monitoring of Egypt's area.

\begin{tabular}{lcc}
\hline & Area $\mathbf{k m}^{2}$ & Area \% \\
\hline Total Egypt's area & 1010000 & 100 \\
Total land area & 999877.0 & 99 \\
Total Water bodies & 10122.7 & $1^{* *}$ \\
Land area with improved land cover & 11976.0 & $1.2^{*}$ \\
Land area with stable land cover & 986085.0 & $98.62^{*}$ \\
Land area with degraded land cover & 1817.0 & $0.18^{*}$ \\
\hline
\end{tabular}

* The area percentage is calculated according to the total land area

** The area percentage is calculated according to the total of Egypt's area

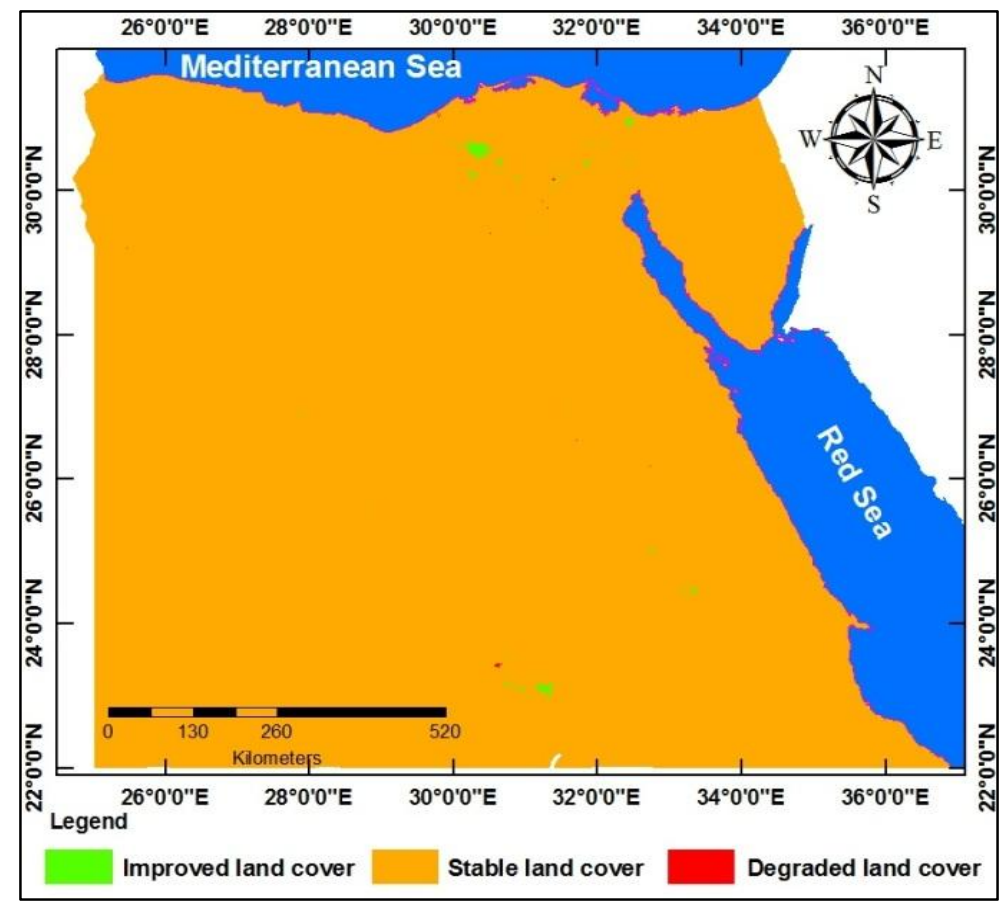

Map 7: Status of land covers change monitoring between 2000 and 2019 for Egypt.

\section{B- Drivers of land cover change}

Egypt could be distinguished into four agro-ecological zones with different land cover/ land use patterns, the changes of which are ascribed to different drivers (Table 5). With respect to the Northern Coastal Zone, land degradation occurs as consequences of overgrazing, accelerated wind/water erosion, removal of natural vegetation and irrational soil and water management as direct drivers. The Nile Delta and valley zone, on the other hand, is negatively influenced by urbanization and infrastructure development, sea water intrusion, depletion of soil fertility, soil salinization, inadequate maintenance of irrigation and drainage network.

In the Western Desert Zone, the main direct drivers are the prevailing climate conditions, irrational utilization of ground water as well as the improper management of land resources. Regarding, the Eastern Desert and Inland Sinai, overgrazing, flash floods and improper management of soil are considered the main drivers. 
Table 5: The main direct and indirect drivers of land cover changes and the consequent land degradation in the four agro-ecological zone of Egypt.

\begin{tabular}{|c|c|}
\hline Direct drivers & Indirect drivers \\
\hline $\begin{array}{l}\text { Zone 1: The No } \\
\text { - Improper management of the soil and water } \\
\text { - Overgrazing and removal of natural vegetation } \\
\text { - Urbanization and infrastructure development } \\
\text { - Wind/water erosion } \\
\text { - Tourism activities, and mining }\end{array}$ & $\begin{array}{l}\text { thern Coastal region } \\
\text { - Seasonal population pressure } \\
\text { - Economical problem of poverty and wealth } \\
\text { - Labour unavailability } \\
\text { - Education, access to knowledge and support services }\end{array}$ \\
\hline $\begin{array}{l}\text { Zone 2: Nile I } \\
\text { - Improper management of the soil } \\
\text { - Scheduling of irrigation and drainage system } \\
\text { - Intensive agriculture } \\
\text { - Urbanization and infrastructure development } \\
\text { - Soil salinization } \\
\text { - Release of air and water borne pollutants }\end{array}$ & $\begin{array}{l}\text { elta and Valley } \\
\text { - Land tenure } \\
\text { - Crop pattern diversion } \\
\text { - Education, and access to knowledge and support } \\
\text { services } \\
\text { - Governmental, institutional settings and policies }\end{array}$ \\
\hline $\begin{array}{l}\text { Zone 3: The } \\
\text { - Improper management of the land resources } \\
\text { - Wind erosion of soil } \\
\text { - Over-abstraction of ground water of aquifer } \\
\text { - Prevailing harsh climatic condition }\end{array}$ & $\begin{array}{l}\text { Vestern Desert } \\
\text { - Economical problem and poverty } \\
\text { - Education, cultural and training programs for } \\
\text { knowledge and support services } \\
\text { - Political support and funding }\end{array}$ \\
\hline $\begin{array}{l}\text { Zone 4: Inland Sin } \\
\text { - Wind and water soil erosion } \\
\text { - Overgrazing } \\
\text { - Industrial tourism activities, waste deposition } \\
\text { and mining }\end{array}$ & $\begin{array}{l}\text { i and the Eastern Desert } \\
\text { - Economical problem and Poverty } \\
\text { - Education, cultural and training programs to knowledge } \\
\text { and support services } \\
\text { - Political support and funding }\end{array}$ \\
\hline
\end{tabular}

\section{Conclusion}

The study pinpointed that Egypt could be distinguished into a number of land cover types e.g. "agro-forest areas", "shrubs, grasslands and sparsely vegetated areas", "cropland", "wetland", "artificial surfaces", "bare land" and "water bodies". With respect to bare lands, the predominating class $(>90 \%$ of the total country area), a noticeable very slight negative change $(1.1 \%)$ was detected, the case that could be ascribed to land reclamation of some desert regions. At the same time, a considerable loss in cropland could be rendered to urbanization as well as the increase in water bodies and wetlands. The irrational utilization of natural resources is regarded as the main driver of land degradation; therefore multidimensional studies are needed to maintain the newly reclaimed lands and step up food production.

\section{Acknowledgment:}

The authors would like to thank the staff members of the National Authority for Remote Sensing and Space Science (NARSS), for helping and providing with the ETM images to complete this work. Thanks are extended to Prof. Dr. El-Sayed Ahmed Abd El-Ghafour, professor emeritus of soil science, Desert Research Center for his valuable help, guidances, comments, valuable suggestions, constructive criticism, and encouragement.

\section{References}

Campbell, J. B., 1987. Introduction to remote sensing. The Guilford Press.

Chan, J.C., K.P. Chan, and A.G.O. Yeh, 2001. Detecting the nature of change in an urban environment: A comparison of machine learning algorithms. Photogrammetric Engineering and Remote Sensing, 67, 213-225.

Dwivedi, R.S., 2001. Soil Resources Mapping: A Remote Sensing Perspective, Remote Sensing Reviews, 20(2), 89-122. http://dx.doi.org/10.1080/02757250109532430

Egyptian Military Survey Authority, 2000. Topographic maps with scale 1:100000, Egyptian Military Survey Authority.

ERDAS Inc., 2018. ERDAS Field Guide (ERDAS Imagine). Atlantic, Georgia, USA. 
ESRI, 2016. Arc GIS Spatial Analyst: Advanced-GIS Spatial Analysis Using Raster and vector data, ESRI, 380 New york, USA.

FAO, 2016. Land Cover Classification System (LCCS): Classification Concepts and User Manual. Food and Agriculture Organization of the United Nations, Rome.

Ghabour, T. and L. Daels, 1993. Mapping and Monitoring of Soil Salinity of ISSN, Egyptian Journal of Soil Science, 33(4), 355-370.

Giri, C., Z. Zhu, and B. Reed, 2005. A comparative analysis of the Global Land Cover 2000 and MODIS land cover data sets. Remote Sensing of Environment, 94, 123-132.

IPPC, 2006. IPCC Guidelines for National Greenhouse Gas Inventories. http://www. ipccnggip.iges.or.jp/public/2006gl/pdf/4_Volume4/V4_03_Ch3_Representation.pdf

Lambin, E.F., H.J. Geist and E. Lepers, 2003. Dynamics of land-use and land- cover change in tropical regions. Annu. Rev. Environ. Resour, 28, 205-241.

Lenney, M.P., C.E. Woodcock, J.B. Collins and H., Hamdi, 1996. The status of agricultural lands in Egypt: The use of multi temporal NDVI features derived from Landsat TM. Remote Sensing Environment, 56, 8-20.

Lillesand, T.M., and R.W. Kiefer, 2000. Remote sensing and image interpretation. John Wiley \& Sons, New York.

Muchoney, D.M. and B. Haack, 1994. Change detection for monitoring forest defoliation. Photogrammetric Engineering and Remote Sensing, 60, 1243-1251.

Roy, D.P., P.E. Lewis and C.O. Justice, 2002. Burned area mapping using multi-temporal moderate spatial resolution data bi-directional reflectance model-based expectation approach. Remote Sensing of Environment, 83, 263-286.

Sadek, S.H.A., 1993. Use of Landsat imagery for monitoring agricultural expansion of East and West Nile Delta, Egypt. Egyptian Journal of Soil Sciences, 33(1), 23-24.

Shalaby, A., M. Aboel Ghar, and R. Tateishi, 2004. Desertification impact assessment in Egypt using low resolution satellite data and GIS. The International Journal of Environmental Studies, 61(4): 375-384.

Singh, A., 1989. Digital change detection techniques using remotely sensed data. International Journal of Remote Sensing, 10, 989-1003.

Springborg, R., 1979. Patrimonialism and policy making in Egypt: Nasser and Sadat and the tenure policy for reclaimed lands. Middle Eastern Studies, 15(1), 49-69.

Suliman, M.K., 1991. Universities and development of the desert land in the ARE. In The second annual university conference, Cairo, 2-5 November.

Thomas, I.L., V.M. Benning and N.P. Ching, 1987. Classification of remotely sensed images. Bristol: Adam Hilger.

UNCCD, 2013. Decision 22/COP.11. Advice on how best to measure progress on strategic objectives 1,2 and 3 of The Strategy. UNCCD, Bonn.

http://www.unccd.int/en/programmes/Science/Monitoring-Assessment/Documents/Decision22COP11.pdf

USGS. 2019. Earth Explorer. http://earthexplorer.usgs.gov/ (Accessed 05.04.15).

Verma, K., R.K. Saxena, A.K. Barthwal and S.N. Desh-mukh, 1994. Remote Sensing Technique for Mapping Salt Affected Soils, International Journal of Remote Sensing, 15(9), 1901-1914. http://dx.doi.org/10.1080/01431169408954215 